\title{
Communication
}

\section{Fullerene Aggregation in Thin Films of Polymer Blends for Solar Cell Applications}

\author{
Camilla Lindqvist ${ }^{1}$, Ellen Moons ${ }^{1}\left(\mathbb{D}\right.$ and Jan van Stam ${ }^{2, *}$ (1) \\ 1 Department of Engineering and Physics, Karlstad University, SE-651 88 Karlstad, Sweden; \\ camilla.lindq@gmail.com (C.L.); Ellen.Moons@kau.se (E.M.) \\ 2 Department of Engineering and Chemical Sciences, Karlstad University, SE-651 88 Karlstad, Sweden \\ * Correspondence: Jan.van.Stam@kau.se; Tel.: +46-54-7002479
}

Received: 30 September 2018; Accepted: 21 October 2018; Published: 23 October 2018

\begin{abstract}
We report on the effects of the film morphology on the fluorescence spectra for a thin film including a quinoxaline-based co-polymer (TQ1) and a fullerene derivative $\left([6,6]-\right.$ phenyl- $C_{71}$-butyric acid methyl ester $\left.-\mathrm{PC}_{70} \mathrm{BM}\right)$. The ratio between the polymer and the fullerene derivative, as well as the processing solvent, were varied. Besides the main emission peak at $700 \mathrm{~nm}$ in the fluorescence spectra of thin films of this phase-separated blend, a broad emission band is observed with a maximum at $520-550 \mathrm{~nm}$. The intensity of this emission band decreases with an increasing degree of mixing in the film and becomes most prominent in thicker films, films with high $\mathrm{PC}_{70} \mathrm{BM}$ content, and films that were spin-coated from solvents with lower $\mathrm{PC}_{70} \mathrm{BM}$ solubility. We assign this emission band to aggregated $\mathrm{PC}_{70} \mathrm{BM}$.
\end{abstract}

Keywords: fullerene aggregation; organic solar cells; fluorescence; organic photovoltaics

\section{Introduction}

The interest in polymer based solar cells has grown rapidly during the last two decades. This technology shows several advantages, all related to its easy manufacturing by solution-based processes, compared to other solar energy harvesting technologies. Today single junction polymer solar cells of binary blends have reached a record efficiency of about $14 \%[1,2]$ and tandem cells even higher, above $17 \%$ [3].

The photoactive layer consists of a blend of an electron-donating polymer and an acceptor molecule. One of the most studied classes of acceptor molecules is fullerene derivatives, such as $[6,6]$-phenyl- $\mathrm{C}_{61}$-butyric acid methyl ester $\left(\mathrm{PC}_{60} \mathrm{BM}\right)$ or $[6,6]$-phenyl- $\mathrm{C}_{71}$-butyric acid methyl ester $\left(\mathrm{PC}_{70} \mathrm{BM}\right)$, but more recently non-fullerene acceptor molecules or polymers have increased in popularity. The donor and acceptor material are typically processed together from a chlorinated and/or aromatic solvent into a thin liquid film. The morphology of the donor/acceptor active layer is formed during deposition when the solvent evaporates and can later be altered through post-production treatments $[4,5]$. The morphology will affect the charge transfer from the donor to the acceptor, as well as the charge transport to the electrodes, and is consequently a crucial factor determining the solar cell performance [6-9].

When a polymer/fullerene blend phase separates, polymer-rich and fullerene-rich domains are formed. The degree of phase separation will depend on several factors, e.g., the solubility of the two materials in the solvent $[10,11]$, their mutual miscibility [12,13], and the rate of drying $[14,15]$. The interaction between the fullerene derivative and the conjugated polymer, as for instance expressed by the Flory-Huggins interaction parameters, plays a significant role in the phase separation [12]. By varying the solvent used for deposition, the solubility and the drying kinetics are affected simultaneously, and the change in morphology is complicated to predict $[10,16-19]$. Microscopy 
techniques, such as atomic force microscopy (AFM), are very suitable to study domain structures of $50 \mathrm{~nm}$ up to several micrometres in diameter. For systems where liquid-liquid phase separation prevails, coarser domain structures will be achieved if the drying time is prolonged by e.g., slower spin-coating speeds $[14,15]$ or solvent annealing. Blends of a quinoxaline-based donor polymer (TQ1) [20] and $\mathrm{PC}_{70} \mathrm{BM}$ (Figure 1) [10,21,22], have been shown to be a material combination that yields solar cell efficiencies up to $7 \%$ [23].

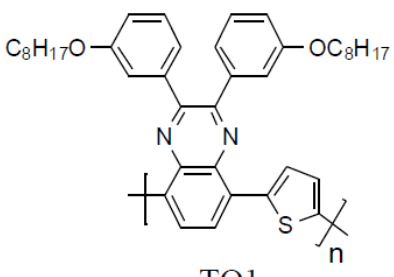

TQ1

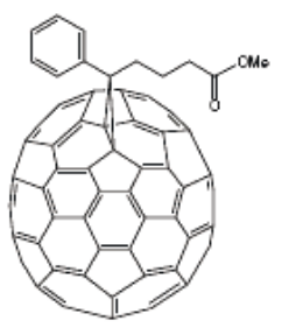

$$
\mathrm{PC}_{70} \mathrm{BM}
$$

Figure 1. Chemical structure of a quinoxaline-based donor polymer (TQ1) and a $[6,6]$-phenyl- $\mathrm{C}_{71}$-butyric acid methyl ester $\left(\mathrm{PC}_{70} \mathrm{BM}\right)$.

In order to access information about the structures on the molecular scale, it is of importance to combine microscopy techniques with others, e.g., fluorescence spectroscopy. Here, we report on the aggregation of $\mathrm{PC}_{70} \mathrm{BM}$, as studied by fluorescence spectroscopy. Fluorescence spectroscopy has successfully been used for the characterisation of these [21,22] or other [24,25] blends previously. The optical properties are correlated with the phase separated domain structure as imaged by AFM.

\section{Materials and Methods}

$\mathrm{PC}_{70} \mathrm{BM}$ (purity $99 \%$ ) was purchased from Solenne, Groningen, The Netherlands. TQ1 was prepared according to previously published procedures [20]. TQ1 had a number-average molecular weight of $M_{\mathrm{n}} \approx 34,000$ (polydispersity index $\approx 2.7$ ) as measured with size exclusion chromatography with a polystyrene standard. Chlorobenzene (CB) and chloroform (CF) (analytical grade) were purchased from Merck (Kenilworth, NJ, USA), ortho-dichlorobenzene (oDCB) (analytical grade) was purchased from Sigma-Aldrich (St. Louis, MO, USA). All solvents were used as received.

\subsection{Solubility Measurements}

Saturated solutions of $\mathrm{PC}_{70} \mathrm{BM}$ were prepared in the three solvents. After equilibration, the solutions were thoroughly centrifuged and an aliquot of known volume of the supernatant was withdrawn. The saturation concentrations were estimated by gravimetric analysis of the dry content after complete solvent evaporation.

\subsection{Thin Film Preparation}

Thin films were spin-coated from CF $(12.5 \mathrm{mg} / \mathrm{mL}), \mathrm{CB}(20 \mathrm{mg} / \mathrm{mL})$, or $o$ DCB $(25 \mathrm{mg} / \mathrm{mL})$ solutions. Concentrations in brackets are the total material concentration in solution in which the ratio between $\mathrm{TQ} 1$ and $\mathrm{PC}_{70} \mathrm{BM}$ was altered. Solutions were gently heated prior to spin-coating, approximately $50{ }^{\circ} \mathrm{C}$ for $\mathrm{CF}$ and $60{ }^{\circ} \mathrm{C}$ for $\mathrm{CB}$ and $o \mathrm{DCB}$. The spin-speed and concentrations were 
chosen to yield thin blend films of similar thickness [10]. The film thickness was approximately $90 \mathrm{~nm}$ $( \pm 10 \mathrm{~nm})$, as measured by AFM, if nothing else is stated. The films were allowed to dry in ambient air. For fluorescence spectroscopy and AFM, silicon wafers were used as substrates, cleaned using the standard RCA method [26-28] without the final HF-etching step, so that a clean and hydrophilic surface is achieved.

\subsection{Steady-State Fluorescence Measurements}

Steady-state fluorescence spectra were collected on a SPEX FL3-11 TAU fluorimeter, purchased from Gammadata (Uppsala, Sweden). Measurements were performed on thin films in front-face mode at a $22^{\circ}$ angle relative to the incident excitation light in order to prevent reflected excitation light. The excitation wavelength was $380 \mathrm{~nm}$. All samples were kept in the dark prior to the measurements and the spectra were recorded at room temperature and in ambient air.

\subsection{Atomic Force Microscopy (AFM)}

Images were collected in tapping mode with a Nanoscope IIIA Multimode AFM (Bruker, Billerica, MA, USA) using a TESPA-V2 n-doped silicon cantilever.

\section{Results and Discussion}

\subsection{Solubility of $P C_{70} B M$}

The solubility of $\mathrm{PC}_{70} \mathrm{BM}$ in $o \mathrm{DCB}$ was determined by gravimetric analysis to be $66 \mathrm{mg} / \mathrm{mL}$, compared to $56 \mathrm{mg} / \mathrm{mL}$ in $\mathrm{CB}$ and $34 \mathrm{mg} / \mathrm{mL} \mathrm{CF}$ [22]. The vapour pressures of the solvents are $0.14 \mathrm{kPa}, 1.5 \mathrm{kPa}$, and $26.3 \mathrm{kPa}$ for $o \mathrm{DCB}, \mathrm{CB}$, and CF, respectively $[29,30]$.

\subsection{Fluorescence Measurements}

To study the relationship between morphology and optical properties, both the solvent for deposition and the ratio between $\mathrm{TQ} 1$ and $\mathrm{PC}_{70} \mathrm{BM}$ were altered. It has been shown earlier that the phase separated domains become larger when the fraction of $\mathrm{PC}_{70} \mathrm{BM}$ is increased in the blend [31] and that the domain size depends on the choice of solvent for films with equal thickness [10]. Hansson et al. have shown that the composition of the phase separated domains is rich in $\mathrm{PC}_{70} \mathrm{BM}$ and, by AFM imaging, that the domains are larger when $\mathrm{CF}$ is used as solvent than when $o \mathrm{DCB}$ is the solvent [10]. The AFM images shown in Figure 2 show that the phase-separated, $\mathrm{PC}_{70} \mathrm{BM}$-rich domains become larger when a worse solvent for the fullerene derivative is used, in line with the earlier findings. This is more pronounced for the 1:3 blend than for the 1:1 blend in the series of decreasing $\mathrm{PC}_{70} \mathrm{BM}$ solubility, i.e., $o$ DCB, $C B$, and CF. Emission spectra, shown in Figure 3, obtained upon excitation at $380 \mathrm{~nm}$ of the blend films show that apart from the main TQ1 emission peak at $700 \mathrm{~nm}$ [21,22], a very broad emission band with a maximum between $520 \mathrm{~nm}$ and $550 \mathrm{~nm}$. For pure TQ1 in solution, this emission band is absent when TQ1 is dissolved in CF, CB or $o$ DCB [22], which is also found for pure TQ1 films (spectrum not shown). The only emission in the visible region from TQ1 dissolved in those solvents is found around $650-700 \mathrm{~nm}$, slightly blue-shifted in comparison with the emission from TQ1 films [21,22]. For TQ1:PC $70 \mathrm{BM}$ blend films, we have shown that when the $\mathrm{PC}_{70} \mathrm{BM}$-rich domains grow, the intensity of the emission band between $500 \mathrm{~nm}$ and $550 \mathrm{~nm}$ increases [22].

A similar trend in the emission peak as in the previous studies is observed if the amount of $\mathrm{PC}_{70} \mathrm{BM}$ was increased (Figure 3a) or if a worse solvent for $\mathrm{PC}_{70} \mathrm{BM}(\mathrm{CF})$ is used (Figure $3 b$ ). Further, the maximum of the 500-550 nm emission band shifts to longer wavelengths, i.e., from approximately $520 \mathrm{~nm}$ to $550 \mathrm{~nm}$, shown in Figure 3. Cook et al. showed that films of pure $\mathrm{PC}_{60} \mathrm{BM}$ give rise to a broad emission band at approximately $500 \mathrm{~nm}$, which is absent when the fullerene derivative is well distributed in a polystyrene matrix (1:7 fullerene/polystyrene) [31]. They assign this emission to the occurrence of aggregated $\mathrm{PC}_{60} \mathrm{BM}$. In addition, Jamieson et al. observed this peak in films of blends with a high fullerene content in a semi-conducting polymer matrix relevant for solar cell 
applications [32]. The emission peak observed in the present $\mathrm{PC}_{70} \mathrm{BM}$-based blends seems to be similar to the one reported for $\mathrm{PC}_{60} \mathrm{BM}$. This series of results indicates that the $520-550 \mathrm{~nm}$ emission band in strongly phase-separated TQ1: $\mathrm{PC}_{70} \mathrm{BM}$ is likely to emanate from aggregated $\mathrm{PC}_{70} \mathrm{BM}$, and that samples with larger domains include a larger portion of aggregated $\mathrm{PC}_{70} \mathrm{BM}$. The nature of these aggregates is not clear from these results. Earlier literature suggests that nanocrystals of fullerenes can be formed upon spin-coating [33]. The shift from $520 \mathrm{~nm}$ to $550 \mathrm{~nm}$ in emission maximum is most likely due to a gradual development of the aggregates from a less organised cluster of $\mathrm{PC}_{70} \mathrm{BM}$ molecules (in films coated from $C B$ and in films with a 1:1 ratio) to more compact aggregates in films with a 1:3 ratio or in films prepared from CF. For the present results, we cannot draw conclusions about the location of the $\mathrm{PC}_{70} \mathrm{BM}$ aggregates, even though it is safe to assume that they are formed inside the $\mathrm{PC}_{70} \mathrm{BM}$-rich domains.

To further underpin this interpretation, films of the 1:3 TQ1:PC ${ }_{70} \mathrm{BM}$ blend with different thicknesses (50-130 $\mathrm{nm}$ ) were prepared [15] by changing the spin-coating speed (Figure 4). Thicker films, resulting from slower spin-coating, demonstrated larger $\mathrm{PC}_{70} \mathrm{BM}$-rich domains as shown in the AFM images (Figure 4a). The corresponding emission spectra (Figure $4 \mathrm{~b}$ ) show that when the film thickness is increased from $90 \mathrm{~nm}$ to $130 \mathrm{~nm}$, the intensity of the emission band increases and the emission maximum shifts from $520 \mathrm{~nm}$ to about $540 \mathrm{~nm}$. Decreasing the film thickness from $90 \mathrm{~nm}$ to $50 \mathrm{~nm}$ does not have a significant effect on the emission band. This confirms that the domains have to reach a certain size before the aggregate emission becomes detectable. These results follow the trends presented by Bäcke et al., where they analysed thermally-induced aggregation of $\mathrm{PC}_{60} \mathrm{BM}$ by transmission electron tomography in blend films of TQ1:PC ${ }_{60} \mathrm{BM}$. They showed that the $\mathrm{PC}_{60} \mathrm{BM}$ crystals grow in size and that the $\mathrm{PC}_{60} \mathrm{BM}$ rich domains start to develop in the upper part of the blend film, yielding crystals in this upper part [34].

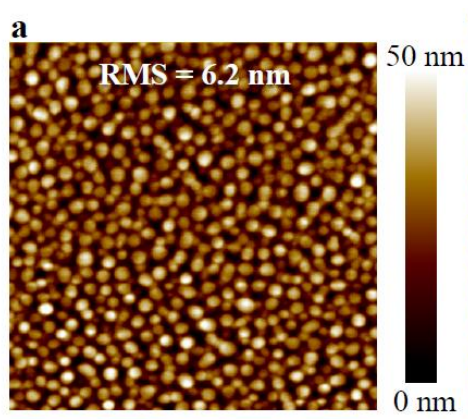

b

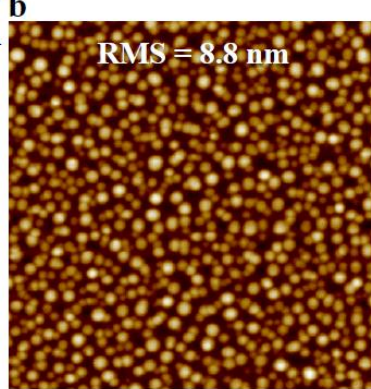

d

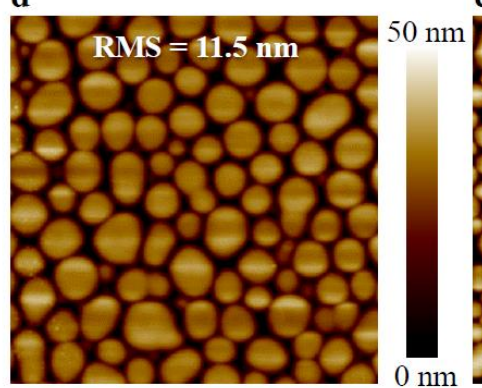

e

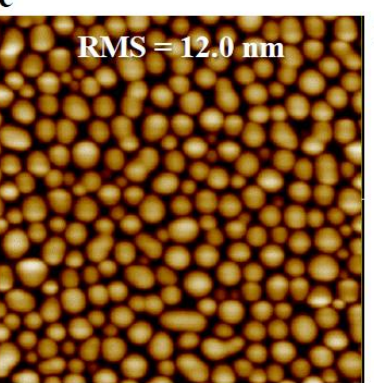

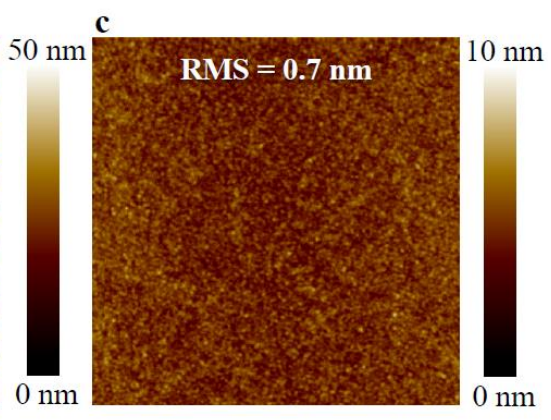

f

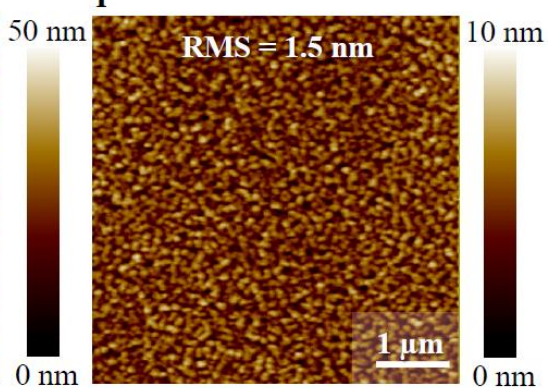

Figure 2. Atomic force microscopy $(\mathrm{AFM})$ micrographs $(5 \times 5 \mu \mathrm{m})$ of thin films of 1:1 TQ1:PC ${ }_{70} \mathrm{BM}$ $(\mathbf{a}-\mathbf{c})$ and 1:3 TQ1:PC $70 \mathrm{BM}(\mathbf{d}-\mathbf{f})$ spin-coated from chloroform $(\mathrm{CF})(\mathbf{a}, \mathbf{d})$, chlorobenzene $(\mathrm{CB})(\mathbf{b}, \mathbf{e})$, and ortho-dichlorobenzene $(o \mathrm{DCB})(\mathbf{c}, \mathbf{f})$. Scale bar indicates $1 \mu \mathrm{m}$. Surface roughness (RMS), as well as the corresponding height scale, is added to each image. 


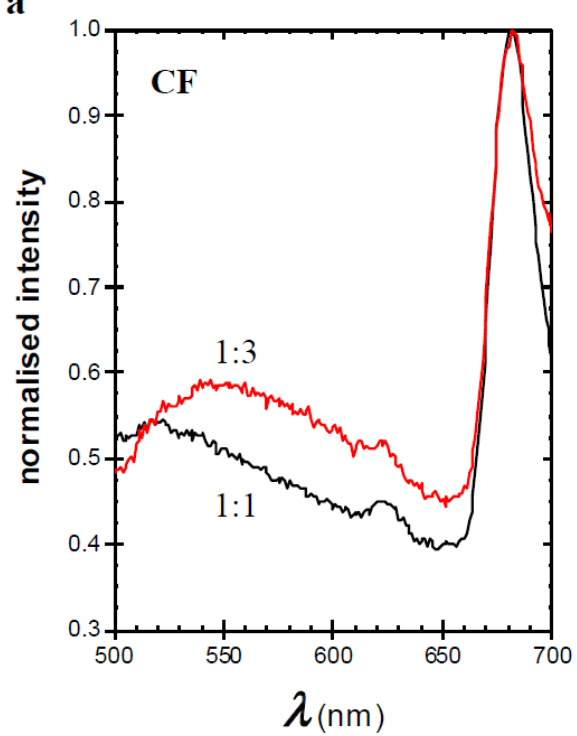

b

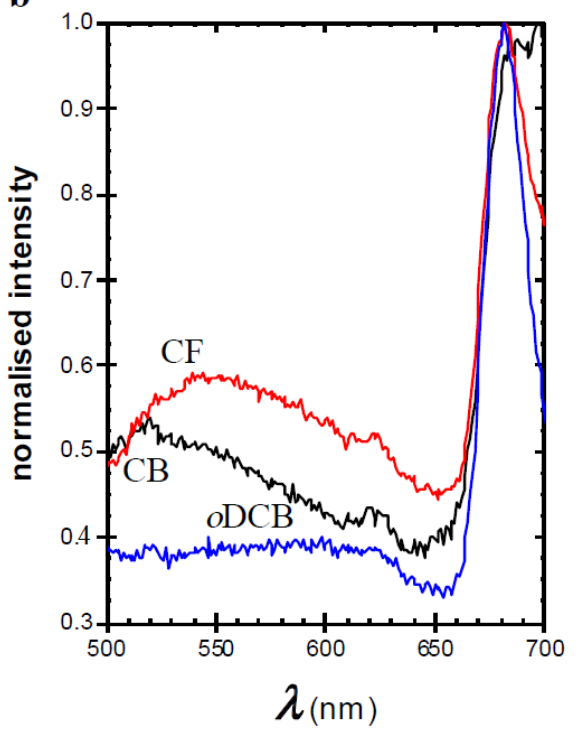

Figure 3. Fluorescence emission spectra of thin films measured with excitation wavelength $\left(\lambda_{\mathrm{ex}}\right)=380 \mathrm{~nm}$ of (a) 1:1 (black) and 1:3 (red) TQ1:PC ${ }_{70} \mathrm{BM}$ spin-coated from CF (b) 1:3 TQ1:PC ${ }_{70} \mathrm{BM}$ spin-coated from CF (red), CB (black), and $o$ DCB (blue).

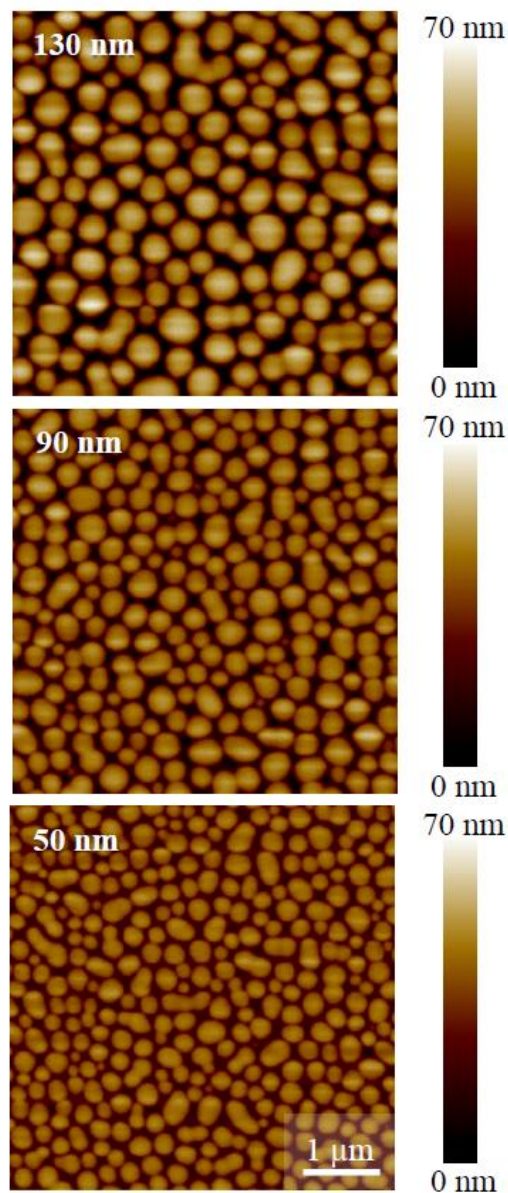

b

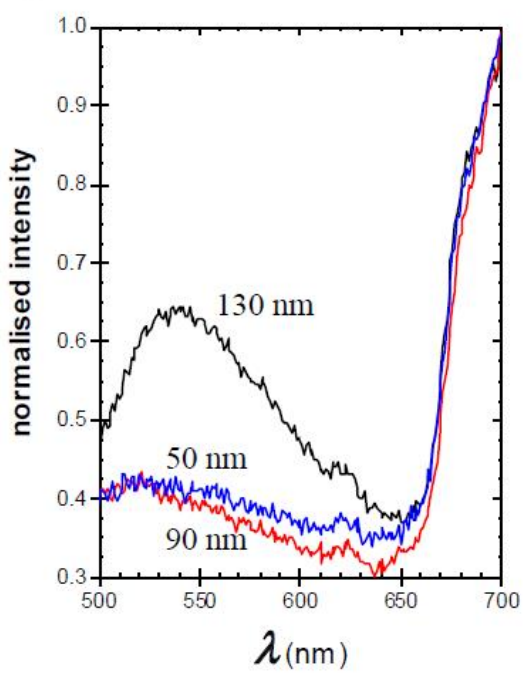

Figure 4. (a) AFM micrographs $(5 \times 5 \mu \mathrm{m})$ of thin films of 1:3 TQ1:PC $70 \mathrm{BM}$ spin-coated from $\mathrm{CB}$ with the indicated film thicknesses. A height scale is added to each image. (b) Corresponding fluorescence emission spectra for films with indicated thicknesses. 


\section{Conclusions}

In this study we have investigated the relationship between the detailed emission spectra analysis of TQ1:PC ${ }_{70} \mathrm{BM}$ blends and the morphology of these blends. Solvents with lower $\mathrm{PC}_{70} \mathrm{BM}$ dissolution capacity as well as an increased $\mathrm{PC}_{70} \mathrm{BM}$ concentration yield larger phase-separated domains. In these larger domains, $\mathrm{PC}_{70} \mathrm{BM}$ aggregates are likely to be formed, resulting in a broad and rather weak emission between $520 \mathrm{~nm}$ and $550 \mathrm{~nm}$ upon excitation at $380 \mathrm{~nm}$. For better $\mathrm{PC}_{70} \mathrm{BM}$ solvents and at lower $\mathrm{PC}_{70} \mathrm{BM}$ concentrations, the fullerene derivative stays well-mixed with the polymer and no emission between $500 \mathrm{~nm}$ and $550 \mathrm{~nm}$ is detected. Further investigation by, e.g., high-resolution microscopy techniques is needed to determine the sizes and locations of these aggregates.

As aggregation of the components in the active layer of an organic solar cell is one of the major degradation paths, leading to a large drop in device efficiency, there is a need to detect and quantify this phenomenon. The methods used to measure aggregation in thin blend films are often both time-consuming and expensive. We have shown that fluorescence spectroscopy offers an easy and fast tool for this purpose, in comparison with other methods. More experimental work has to be done in order to further develop this method.

Author Contributions: Experimental work and measurements, C.L.; all authors share the responsibility of all other parts of this communication.

Funding: J.v.S. acknowledges the funding from the Swedish National Space Agency under contracts 148/16 and 185/17. E.M. acknowledges the Göran Gustafsson Foundation for Research in Natural Sciences and Medicine. J.v.S. and E.M. acknowledge the funding from the Knut and Alice Wallenberg foundation under contract 2016.0059.

Acknowledgments: The authors acknowledge Ergang Wang (Chalmers University of Technology, Gothenburg, Sweden) for providing TQ1. Rickard Hansson, Leif Ericsson, and Mikael Andersén (Karlstad University) are acknowledged for valuable discussions and technical support. In addition, Bo Albinsson (Chalmers University of Technology) is acknowledged for making his SPEX fluorimeter available for troubleshooting.

Conflicts of Interest: The authors declare no conflict of interest.

\section{References}

1. Zhao, W.; Li, S.; Yao, H.; Zhang, S.; Zhang, Y.; Yang, B.; Hou, J. Molecular Optimization Enables over 13\% Efficience in Organic Solar Cells. J. Am. Chem. Soc. 2017, 139, 7148-7151. [CrossRef] [PubMed]

2. Li, S.; Ye, L.; Zhao, W.; Yan, H.; Yang, B.; Liu, D.; Li, W.; Ade, H.; Hou, J. A Wide Bandgap Polymer with a Deep Highest Occupied Molecular Orbital Level Enables 14.2\% Efficiency in Polymer Solar Cells. J. Am. Chem. Soc. 2018, 140, 7159-7167. [CrossRef] [PubMed]

3. Meng, L.; Zhang, Y.; Wan, X.; Li, C.; Zhang, X.; Wang, Y.; Ke, X.; Xiao, Z.; Ding, L.; Xia, R.; et al. Organic and solution-processed tandem solar cells with 17.3\% efficiency. Science 2018, 361, 1094-1098. [CrossRef] [PubMed]

4. Ma, W.; Yang, C.; Gong, X.; Lee, K.; Heeger, A.J. Thermally Stable, Efficient Polymer Solar Cells with Nanoscale Control of the Interpenetrating Network Morphology. Adv. Funct. Mater. 2005, 15, 1617-1622. [CrossRef]

5. $\quad$ Bergqvist, J.; Lindqvist, C.; Bäcke, O.; Ma, Z.; Tang, Z.; Tress, W.; Gustafsson, S.; Wang, E.; Olsson, E.; Andersson, M.R.; et al. Sub-glass transition annealing enhances polymer solar cell performance. J. Mater. Chem. A 2014, 2, 6046-6152. [CrossRef]

6. Morvillo, P.; Bobeico, E.; Esposito, S.; Diana, R. Effect of the active layer thickness on the device performance of polymer solar cells having [60]PCBM and [70]PCBM as electron acceptor. Energy Procedia 2012, 31, 69-73. [CrossRef]

7. Bruno, A.; Villani, F.; Grimaldi, I.A.; Loffredo, F.; Morvillo, P.; Diana, R.; Haque, S.; Minarini, C. Morphological and spectroscopic characterizations of inkjet-printed poly(3-hexylthiophene-2,5-diyl): Phenyl-C61-butyric acid methyl ester blends for organic solar cell applications. Thin Solid Films 2014, 560, 14-19. [CrossRef]

8. Morvillo, P.; Ricciardi, R.; Nenna, G.; Bobeico, E.; Diana, R.; Minarini, C. Elucidating the origin of the improved current output in inverted polymer solar cells. Sol. Energy Mater. Sol. Cells 2016, 152, 51-58. [CrossRef] 
9. Lee, H.; Park, C.; Sin, D.H.; Park, J.H.; Cho, K. Recent Advances in Morphology Optimization for Organic Photovoltaics. Adv. Mater. 2018, 30, 1800453. [CrossRef] [PubMed]

10. Hansson, R.; Ericsson, L.K.E.; Holmes, N.P.; Rysz, J.; Opitz, A.; Campoy-Quiles, M.; Wang, E.; Barr, M.G.; Kilcoyne, A.L.D.; Zhou, X.; et al. Vertical and lateral morphology effects on solar cell performance for a thiophene-quinoxaline copolymer:PC ${ }_{70}$ BM blend. J. Mater. Chem. A 2015, 3, 6970-6979. [CrossRef]

11. Voigt, M.; Chappell, J.; Rowson, T.; Cadby, A.; Geoghegan, M.; Jones, R.A.L.; Lidzey, D.G. The interplay between the optical and electronic properties of light-emitting-diode applicable conjugated polymer blends and their phase-separated morphology. Org. Electron. 2005, 6, 35-45. [CrossRef]

12. Nilsson, S.; Bernasik, A.; Budkowski, A.; Moons, E. Morphology and Phase Segregation of Spin-Casted Films of Polyfluorene/PCBM Blends. Macromolecules 2007, 40, 8291-8301. [CrossRef]

13. Ma, Z.; Wang, E.; Vandewal, K.; Andersson, M.R.; Zhang, F. Enhance performance of organic solar cells based on an isoindigo-based copolymer by balancing absorption and miscibility of electron acceptor. Appl. Phys. Lett. 2011, 99, 143302. [CrossRef]

14. Kouijzer, S.; Michels, J.J.; van den Berg, M.; Gevaerts, V.S.; Turbiez, M.; Wienk, M.M.; Janssen, R.A.J. Predicting Morphologies of Solution Processed Polymer:Fullerene Blends. J. Am. Chem. Soc. 2013, 135, 12057-12067. [CrossRef] [PubMed]

15. van Franeker, J.J.; Westhoff, D.; Turbiez, M.; Wienk, M.M.; Schmidt, V.; Janssen, R.A.J. Controlling the Dominant Length Scale of Liquid-Liquid Phase Separation in Spin-coated Organic Semiconductor Films. Adv. Funct. Mater. 2015, 25, 855-863. [CrossRef]

16. Shaheen, S.E.; Brabec, C.J.; Sariciftci, N.S.; Padinger, F.; Fromherz, T.; Hummelen, J.C. 2.5\% efficient organic plastic solar cells. Appl. Phys. Lett. 2001, 78, 841-843. [CrossRef]

17. Rispens, M.T.; Meetsma, A.; Rittberger, R.; Brabec, C.J.; Sariciftci, N.S.; Hummelen, J.C. Influence of the solvent on the crystal structure of PCBM and the efficiency of MDMO-PPV:PCBM 'plastic' solar cells. Chem. Commun. 2003, 2116-2118. [CrossRef]

18. Martens, T.; D’Haen, J.; Munters, T.; Beelen, Z.; Goris, L.; Manca, J.; D’Olieslaeger, M.; Vanderzande, D.; De Schepper, L.; Andriessen, R. Disclosure of the nanostructure of MDMO-PPV:PCBM bulk hetero-junction organic solar cells by a combination of SPM and TEM. Synth. Met. 2003, 138, 243-247. [CrossRef]

19. Yang, X.; van Duren, J.K.J.; Janssen, R.A.J.; Michels, M.A.J.; Loos, J. Morphology and Thermal Stability of the Active Layer in Poly(p-phenylenevinylene)/Methanofullerene Plastic Photovoltaic Devices. Macromolecules 2004, 37, 2151-2158. [CrossRef]

20. Wang, E.; Hou, L.; Wang, Z.; Hellström, S.; Zhang, F.; Inganäs, O.; Andersson, M.R. An Easily Synthesized Blue Polymer for High-Performance Polymer Solar Cells. Adv. Mater. 2010, 22, 5240-5244. [CrossRef] [PubMed]

21. van Stam, J.; Hansson, R.; Lindqvist, C.; Ericsson, L.; Moons, M. Fluorescence spectroscopy studies on polymer blend solutions and films for photovoltaics. Colloid Surf. A Physicochem. Eng. Asp. 2015, 483, 292-296. [CrossRef]

22. van Stam, J.; Lindqvist, C.; Hansson, R.; Ericsson, L.; Moons, E. Fluorescence and UV/VIS absorption spectroscopy studies on polymer blend films for photovoltaics. Proc. SPIE 2015, 9549, 95490L. [CrossRef]

23. Kim, Y.; Yeom, H.R.; Kim, J.Y.; Yang, C. High-efficiency polymer solar cells with a cost-effective quinoxaline polymer through nanoscale morphology control induced by practical processing additives. Energy Environ. Sci. 2013, 6, 1909-1916. [CrossRef]

24. van Stam, J.; Van fraeyenhoven, P.; Andersén, M.; Moons, E. Comparing Morphology in Dip-Coated and Spin-Coated Polyfluorene: Fullerene Films. Proc. SPIE 2016, 9942, 99420D. [CrossRef]

25. van Stam, J.; Ericsson, L.; Deribew, D.; Moons, E. Morphology in Dip-Coated Blend Films for Photovoltaics Studied by UV/VIS Absorption and Fluorescence Spectroscopy. Proc. SPIE 2018, 10687, 10687A. [CrossRef]

26. Kern, W.; Puotinen, D.A. Cleaning Solutions Based on Hydrogen Peroxide for Use in Silicon Semiconductor Technology. RCA Rev. 1970, 31, 187-206.

27. Kern, W. The Evolution of Silicon Wafer Cleaning Technology. J. Electochem. Soc. 1990, 137, 1887-1892. [CrossRef]

28. Kissinger, G.; Kissinger, W. Hydrophilicity of Silicon Wafers for Direct Bonding. Phys. Stat. Sol. 1991, 123, 185-192. [CrossRef] 
29. Shiu, W.-Y.; Ma, K.-C. Temperature Dependence of Physical-Chemical Properties of Selected Chemicals of Environmental Interest. II. Chlorobenzenes, Polychlorinated Biphenyls, Polychlorinated Dibenzo-p-dioxins, and Dibenzofurans. J. Phys. Chem. Ref. Data 2000, 29, 387-462. [CrossRef]

30. Boublik, T.; Fried, V.; Hala, E. The Vapour Pressures of Pure Substances, 2nd ed.; Elsevier: Amsterdam, The Netherlands, 1984.

31. Cook, S.; Ohkita, H.; Kim, Y.; Benson-Smith, J.J.; Bradley, D.D.C.; Durrant, J.R. A photophysical study of PCBM thin films. Chem. Phys. Lett. 2007, 445, 276-280. [CrossRef]

32. Jamieson, F.C.; Domingo, E.B.; McCarthy-Ward, T.; Heeney, M.; Stingelin, N.; Durrant, J.R. Fullerene crystallisation as a key driver of charge separation in polymer/fullerene bulk heterojunction solar cells. Chem. Sci. 2012, 3, 485-492. [CrossRef]

33. Yang, X.; van Duren, J.K.J.; Rispens, M.T.; Hummelen, J.C.; Janssen, R.A.J.; Michels, M.A.J.; Loos, J. Crystalline Organization of a Methanofullerene as Used for Plastic Solar-Cell Applications. Adv. Mater. 2004, 16, 802-806. [CrossRef]

34. Bräcke, O.; Lindqvist, C.; Diaz de Zerio Mendaza, A.; Gustafsson, S.; Wang, E.; Andersson, M.R.; Müller, C.; Olsson, E. Mapping fullerene crystallization in a photovoltaic blend: An electron tomography study. Nanoscale 2015, 7, 8451-8456. [CrossRef] [PubMed]

(C) 2018 by the authors. Licensee MDPI, Basel, Switzerland. This article is an open access article distributed under the terms and conditions of the Creative Commons Attribution (CC BY) license (http:/ / creativecommons.org/licenses/by/4.0/). 